ISSN 2449-7479

eISSN 2543-8840

amme.wne.sggw.pl

Annals of Marketing Management \& Economics

Vol. 4, No 1, 2018, 35-51

DOI 10.22630/AMME.2018.4.1.3

\title{
SYNERGY AND DIVERSITY OF THE RESOURCES OF AN ENTERPRISE. KNOWLEDGE MANAGER - MODEL APPROACH
}

\author{
Michał A. Leśniewski \\ Jan Kochanowski University in Kielce, Poland \\ Wioletta M. Pacholarz \\ AGH University of Science and Technology, Poland \\ „All our knowledge has its origins in our perceptions.” \\ Leonardo da Vinci
}

\section{INTRODUCTION}

Shaping the development of an enterprise ${ }^{1}$ in a market economy based on competition requires multi-faceted view on the management of an economic operator. The manager and his subordinates, who are the human resource of an organisation, are some of the basic problems connected with the management of an enterprise. The managers together with the subordinates, and especially the positive relations among them, build constructive foundation for the future of the company. What distinguishes managers and subordinates is the knowledge they have and the skills to use that knowledge [Mikuła and Pietruszka-Ortyl 2007]. From the point of view of the process of management it is the manager (decision-maker) who is the person leading the organisation on the "roads" of operational and strategic development. The knowledge for a manager - using a metaphor - is like "water driving the mill wheel". The manager and knowledge should be treated as a complementary and synergistic system in an organisation. Each organisation which

\footnotetext{
${ }^{1}$ In the following study the term "enterprise" is used interchangeably with terms: "economic operator", "organisation", "firm" in order to avoid frequent repetitions.
} 
wants to be an active participant of the competitive market should have a knowledge manager within its ranks, for whom the synergy and diversity of the resources are permanently inscribed in the development of the company.

The aim of the study is to present the problem of synergism and diversity of the resources of an enterprise with the presentation of the original concept of the model of knowledge manager. The following hypotheses were adopted in the study: knowledge manager is the creator of synergy and diversity of the resources of an enterprise; objectiveness of a manager is created by the knowledge and the ability to use it; knowledge manager can manifest himself in the form of material and immaterial concept. The study is conceptual nature and is based on the method of interpretation of literature.

\section{PEOPLE IN AN ENTERPRISE THAT IS MANAGER AND SUBORDINATES}

Enterprise management structure in a volatile environment force the employees to be flexible and open to new challenges. The employees undergo permanent process of learning (knowledge acquisition). According to the guru of management, Peter Drucker, organisation, which consolidates the current level of vision, performance and achievements, loses the ability to adapt and will not be able to survive in the changing tomorrow, as change is the only destiny of a human being [Drucker 1994].

The answer of management to people (human) in an organisation (enterprise) is the management of human resources, which is defined as the activity of an organisation aimed at the achievement, development and maintenance of the manpower functioning effectively [Griffin 2005]. An enterprise is for the human and an economic operator would not be able to function without him. It can be said that man is the basic, primal resource of an organisation (enterprise) [Leśniewski 2014]. Man is different is every aspect, range of his functioning, including, inter alia: needs, sensations, interpretations, intuition or skills and abilities etc. People are different just as different are the resources and situations, because no situation can be repeated twice, as it involves different people with different abilities and skills. Each situation, moment is inimitable and unique. If we approach each employee always in the same way, we will not give a chance to develop, to learn and to use one's abilities - neither to us, nor to him.

The existence of a man in an organisation [Oczkowska 2014] is related to a work, which should not be determined only by such factors as: material and family factors. The selection of work should think through and matched to the skills and abilities of each person, as well as to the level of his commitment. Then we can talk about the development and growth of knowledge, which may affect the increase of efficiency of work or other achieved measurands (i.e. increase of the level of education).

Knowledge concerns every person in the organisation regardless of whether he is a manager or a subordinate. Human resources in an organisation are divided into two systems ${ }^{2}$ : managers' system and subordinates' system. Each of these systems is to represent a specified level of knowledge. The knowledge of a manager is not only the substantive

${ }^{2}$ Each of these systems is homogeneous or uniform consisting only of managers at different levels of management (system of managers) and subordinates (system of subordinates). 
knowledge (i.e. in the field of corporate finance, marketing or logistics, etc.), but also the knowledge in the scope of the process [Sułkowski 2012] of impact on subordinates which is a part of the overall process of human resources' management [Pocztowski 2003] in a given enterprise ${ }^{3}$. Whereas, the knowledge of a subordinate is mainly the substantive knowledge connected with a given job position, work done. Both the manager and the subordinate are to be a complementary link of values [Romanowska 2001, Jaki 2012] of an enterprise. The manager and the subordinate may be defined as a task group ${ }^{4}$.

The issue of the level of appreciation of knowledge requires commitment and will to take challenges and achievements from the manager and the subordinate. A manager who works with a subordinate (task team) successfully and effectively requires full commitment from both sides. A task team is to contribute to the positive effect of synergy. In a task team, mutual understanding, when the employees understand the managers and the managers understand the employees, is very important. The task of the managers in the task force is to understand the needs and the intensity of occurrence of these needs in workers, the hierarchy of values, as well as the skills of the employees. The ability of the recognition and matching the employees to the work in a task team is a proof of the size of substantive level of a manager [Juchnowicz 2009].

\section{RESOURCING AND THE RESOURCES IN AN ENTERPRISE - THE VARIETY OF RESOURCES}

The basis of the enterprise's functioning are its resources, thanks to which the economic operator may shape its competitiveness [Przybytniowski 2013] (resource competitiveness) and competitive advantage (resource competitive advantage).

The resources of an enterprise are inseparably connected to the process [Cyfert 2006] of resourcing. In order for the resources and the resourcing to successfully and efficiently shape the competitiveness and the competitive advantage of an enterprise they must be of complementary nature to each other. Resourcing is a qualitative and quantitative process of obtaining and shaping the resources by an organisation. Obtaining is understood as acquiring, purchasing resources by an organisation. Shaping is understood as creating goods (products/services) from the acquired resources by an organisation [Leśniewski 2014]. It can be argued that resourcing and resources contribute to the development of competitiveness and competitive advantage of the company. Starting with an analysis of resources and resourcing of an economic operator, one must start from the resourcing, as the quality and quantity of resources in the organisation depend on it. Considering the quality and quantity of resources, one should focus more on the quality of resources, because by the quality of the resources the organisation will shape the quality of their goods (products/services).

\footnotetext{
${ }^{3}$ In this case, psychological or sociologic knowledge is also used.

${ }^{4}$ In task team a manager and a subordinate create various interactions between each other. One of the manifestations of a task team is management through aims or management through partner relations. A manager and a subordinate are to be a well-matched par of people in an organisation, who understand each other.
} 
The resources of an enterprise are the assets of differential nature, that is to say a set of available factors controlled by a given enterprise. Resource approach stems from an interest in resources as a key centre of business activity. Since the 1990s it has been dominating approach towards the management of an enterprise, which the development of this theory known today come from, such as: the concept of key competences, learning organisation, knowledge management. Equipped with the unique resources the company is able to achieve a competitive position on the market, to obtain certain income, as well as to increase its value [Skowronek-Mielczarek 2012]. The development and market success are not guaranteed by only having the resources by the organisation, but by the ability of their rational use in changing environmental conditions [Leśniewski 2014].

The enterprises use various resources in their development, among which general resources include: human, monetary (financial), physical, information, knowledge and relational resources. Human resources are the people (employees) and what they stand for, financial resources refer to the financial capital, physical resources are the raw materials, buildings, machines, devices, etc., whereas information and knowledge resources are the news (information) and objectiveness (knowledge) of the employees, which are used by the organisations to the decision-making process. Relational resources refer to the relations among the employees in an organisation (endogenous relations) and the relations of an organization with other organisations operating in the external environment (exogenous relations).

General division of the resources may be also supplemented by natural environment resources and organisational culture resources. Natural environment resources are concerned with not only the natural resources or the atmosphere, hydrosphere and lithosphere, but also the approach (relation) of an organisation (enterprise) towards the natural environment, which is expressed by: environmental awareness and "eco-developmental" awareness 5 . Environmental awareness stands for the approach of an organisation to nature (organisation - natural environment) whereas "eco-developmental awareness" is simultaneous perception of the relationship between the organisation and systems: social - economic - natural environment (organisation - society - economy - natural environment). Environmental awareness is the foundation of "eco-developmental awareness". Organisational culture resources are the norms and values of the employees, which are shaped by the internal and external environment of an organisation ${ }^{6}$.

The general division of the resources of an enterprise is presented in Figure 1.

In order for the resources presented in Figure 1 to shape the competitiveness of an enterprise efficiently and successfully they need to be complementary towards one another, they must generate positive effect of synergy, that is to say, they must interact with each other. Undoubtedly, the relationship between resources will contribute to the synergy and complementarity of resources. It should be kept in mind that it is the people (employees) in an enterprise who are the creators of the resources of an enterprise. Thanks to the employees, that is to say the human resources, the remaining resources have the nature and sense assigned in an enterprise. The human resource is the primary resource and the

\footnotetext{
${ }^{5}$ The author of the term and definition of "eco-developmental awareness" is Michał A. Leśniewski "Eco-developmental awareness" was first published in Leśniewski 2013.

${ }^{6}$ Other: internal and external surroundings.
} 


\begin{tabular}{|c|}
\hline General resources of an enterprise \\
\hline human resources \\
\hline financial resources \\
\hline physical resources \\
\hline information and knowledge resources \\
\hline relational resources \\
\hline natural environment resources \\
\hline organisational culture resources \\
\hline
\end{tabular}

FIG. 1. General division of the resources of an enterprise

Source: the authors based on Skowronek-Mielczarek 2012, Leśniewski 2014.

remaining resources are secondary resources [Leśniewski 2014]. The quality of other resources depends from the quality of human resources.

In the literature there are many divisions of the resources of an organisation. These resources are divided into not only i.e. "material" and "intangible" or "primary" and "secondary" ", but also into "measurable" and "immeasurable". The division of the resources into measurable and immeasurable was created by K. Haanes and B. Lowendahl. They classify the immeasurable resources into competence [Wojtczuk-Turek 2008, Kozina 2014] and relations, and then they divide competence into individual and organisational, whereas relations are seen as: reputation, loyalty of a client, loyalty of the employees. The division of the resources into measurable and immeasurable is presented in Figure 2.



Figure 2. Division of the resources into measurable and immeasurable Source: own elaboration based on Dobija 2003.

${ }^{7}$ The division of the resources into "primary" and "secondary resources" was created by Michał A. Leśniewski. This division was first published in the study [Leśniewski 2014]. 
The resources in an enterprise may be seen as measurable and irrational which is shown in figure 2 . The measurability may be perceived as "something" that one can give a specific dimension to (it can be measured, can subject to dimensioning). The financial (monetary) assets are an example of measurability. In this case, the measurability may be included into the quantitative aspect of the resources, whereas the irrationality may be understood as "something" that cannot or is very difficult to be given a specific dimension. In this case, the irrationality may be included into the qualitative aspect of the resources. Intuition id an example of irrationality.

The literature provides a lot of divisions of resources which enhance the value of organisation's functioning. Multi-faceted approach to resources creates a view that enterprises cannot function without resources whereas having resources does not guarantee the achievement of success by an economic operator. To complete happiness one needs resources and abilities to use them rationally (resources + abilities $=$ rational use of resources, rationality of an organisation $)^{8}$.

One of the issues, problems connected with the functioning of resources in an enterprise is term diversity, which refers to everything that surrounds on the outside and which lies within and which contributes to the development of an organisation. "Diversity may be generally defined as distinctness, otherness, differentiation, which may refer to the human (employee) located in different situations and to an organisation having to deal with changing market conditions"9. Human traits that differ him from other people are, inter alia: sex, age, race, ethnicity, disability, sexual orientation, skills, education, work experience, life attitude, lifestyles, learning styles, human behaviourism or type of properness. The issue of diversity can be transposed from a general, wide grasp to the field of enterprise resources. "Diversity of resources may be defined as distinctness, otherness, differentiation of particular resources in comparison to other resources within a given organisation and/or in relation to other organisations within the external surroundings (external environment)" ${ }^{\text {"10 }}$. Some of the examples which confirm the diversity of resources are divisions, classifications of resources, i.e. division of the resources into material and intangible resources. Such division introduces the resources into the issue of diversity, because each resource has different features, attributes etc. It can be said that, how different is the staff so different are the resources; how different managers are so different are the styles of interaction etc. The diversity can be managed, therefore one can talk about diversity management. Diversity is very important for shaping the knowledge, because each enterprise has to deal with different knowledge.

\footnotetext{
${ }^{8}$ Entry in brackets was formulated by Leśniewski Michał Adam.

${ }^{9}$ Definition of the term "diversity" was formulated by Michał A. Leśniewski and was first published in this elaboration.

${ }^{10}$ Definition of the term "diversity of resources" was formulated by Michał A. Leśniewski and was first published in this elaboration.
} 


\section{KNOWLEDGE AS A MANIFESTATION OF OBJECTIVENESS OF EMPLOYEES AND GENERATING ENTERPRISE'S RESOURCES}

One of the aspects of functioning of resources in an enterprise is, inter alia, knowledge [Mikuła 2006], which is the objectiveness of the employees (managers and subordinates) and the objectiveness of the whole organisation.

Knowledge [Pacholarz 2016] as a resource can be divided, classified which leads to the fact that knowledge may divided into "formal" and "informal knowledge"11. "Formal knowledge" is knowledge set and saved (settled in paper elaborations and electronic studies). "Informal knowledge" is not fixed and not saved, it is the opposite of formal knowledge. "Informal knowledge" may be called unofficial or gossip knowledge. This knowledge is passed on the principle of: "I've learned from a conversation with..., that..." and/or „I've found out informally that...” etc.

Development of effective methods of management of appreciation of the value of knowledge in the company has its reflection not only in competitiveness, but also in the competitive advantage of an economic operator. Organisational creation of knowledge is an ability of a corporation as a whole to produce new knowledge, to spread it in an organisation and to incorporate it in products, services and systems of an organisation [Nonaka and Takeuchi 2000]. Human knowledge is an available knowledge and a hidden knowledge [Nonaka and Takeuchi 2000]. Available knowledge is a knowledge which we have access to, which can be measured, studied, passed on in a formalized form. Hidden knowledge is difficult to formalize, it includes intuition, premonition, sensation and individual activity and experience [Nonaka and Takeuchi 2000]. The value of knowledge in an organisation may be reduced to the statement that people do not achieve new knowledge in a passive way: they interpret it and adapt it to their own situation and perspective [Nonaka and Takeuchi 2000].

At the beginning of the analysis of knowledge in the organization one must first answer the question: What way does the knowledge emerges in? According to the concept of the authorities in the field of knowledge, Nonaka I. and Takeuchi H., the process of knowledge creation is presented in six stages: "dimension of knowledge creation, types of knowledge, ways of knowledge conversion, spiral of knowledge, the essence of knowledge created in four ways and spiral of organizational knowledge creation" [Nonaka and Takeuchi 2000].

Dimension of knowledge creation. Nonaka and Takeuchi propose two dimensions of knowledge creation: "epistemic" and "ontologic". "Epistemic" dimension is a result of separating the object and subject of perception, in other words, separation of the available knowledge from the hidden knowledge. "Ontologic" dimension refers to organisational intensification and including individual knowledge in the system of organisation's knowledge. This process begins with a single member of an organisation, through group interaction reaches with its size to the processes inside an organisation, and then to international processes.

${ }^{11}$ It is one of main divisions of knowledge in an organisation. 
Within these two dimensions of knowledge it can be stated that each man (employee) receives and transmits the acquired knowledge in such a way in which he picked it up and interpreted it in his own way. Interpretation is a very important component of generating knowledge in both business science and practice.

Types of knowledge. Nonaka and Takeuchi divide knowledge into hidden knowledge (subjective), which is a practice created simultaneously, that is to say "here and now", and "available knowledge" (objective), which is based on created theories and mind. The analysis of this knowledge indicates that in the process of knowledge creation there is a process of transformation which is based on creating available knowledge - rational (in the mind) through the hidden knowledge - experimental (in the body).

Ways of knowledge conversion. Through a process of social conversion the hidden and available knowledge grow, both in terms of qualitative and quantitative sense [Nonaka and Takeuchi 2000]. The process of conversion takes place when it happens between various people, not inside an individual.

Spiral of knowledge. It is based on the fact that interactions, which take place in the process of creating knowledge, are shaped by the movements happening between various types of conversion, which in turn are initiated by four forces, that is to say: building ground, dialogue, connecting available knowledge and learning in action. It is a dynamic process between the hidden and available knowledge. This process is followed by another - creating the knowledge in four ways [Nonaka and Takeuchi 2000].

The essence of knowledge created in four ways. Created knowledge is diverse. Each of its processes provides different knowledge, that is to say "process of socialization" provides co-felt knowledge; "externality" - conceptual knowledge; "internalisation" - operational knowledge, and "combination" - structured knowledge [Nonaka and Takeuchi 2000].

Spiral of organisational knowledge creation. The knowledge of each individual man that is to say the hidden knowledge of individuals is the basis of creating the knowledge resource in an enterprises. The task of an organisation is to gather such knowledge, mobilising it and turning it into knowledge available to each employee. The spiral of organisational knowledge creation is concerned with coincident growth of knowledge at the ontologic level with the increase of the range of interaction between available and hidden knowledge.

Knowledge [Perechuda 2005, Rzepka 2015] accompanies a man (employee) and an organisation (enterprise) not only in shaping the competitiveness, but also in achieving the competitive advantage on the market. Taking into account the level of an employee and of an organisation, knowledge may be divided into: "employee knowledge" and "organisational knowledge".

"Employee knowledge" is a theoretical knowledge and the knowledge of work experience with the abilities to use these two types of knowledge together in the practice of functioning of an employee in an organisation. "Employee knowledge" is also the theoretical knowledge with the ability to further use it by an employee of an organisation. Taking such presentation of "employee knowledge" it can be stated that the employee knowledge with the advantage of knowledge of work experience (practical) over the theoretical knowledge may be defined as "practical employee knowledge" and employee knowledge with the advantage of theoretical knowledge over practical knowledge (or the lack of practical knowledge) may be defined as "theoretical employee knowledge". What 
connects the practical and theoretical employee knowledge is "the ability to use knowledge" in an organisation. Each employee must be able to create his own "bridge", notice the dependency between the knowledge (types of knowledge) he has and the effects of that knowledge (these types of knowledge). Both theoretical and practical (work) knowledge must be complementary in order to generate positive effect of synergy.

"Organisational knowledge" is knowledge of all the employees used for operational and strategic functioning of an organisation on the market. Taking into account the fact that organisational knowledge is concerned with the knowledge of the employees and the organisation cares for it to be developing qualitatively, the organisation must employ and try to keep qualitative employees, because they are the proof of the whole organisation (enterprise) being substantial. A substantive employee is the core of the quality of an organisation. Such employee matches the organisational structure and the specificity of an enterprise. It can be stated that a substantive employee is a substantive organisation. "Organisational knowledge" may be divided into "practical organisational knowledge" and "theoretical organisational knowledge". "Practical organisational knowledge" is the advantage of practical knowledge over the theoretical knowledge of all the employees of an organisation. "Theoretical organisational knowledge" is the advantage of theoretical knowledge over the practical knowledge of all the employees of an organisation. In Figure 3 the division of knowledge into employee and organisational knowledge was presented.

The analysis of the division of knowledge presented in Figure 3 states that in order for the employee and organisational knowledge to contribute to the development of an organisation, they must take form of "integrated knowledge" (cumulative knowledge), in other

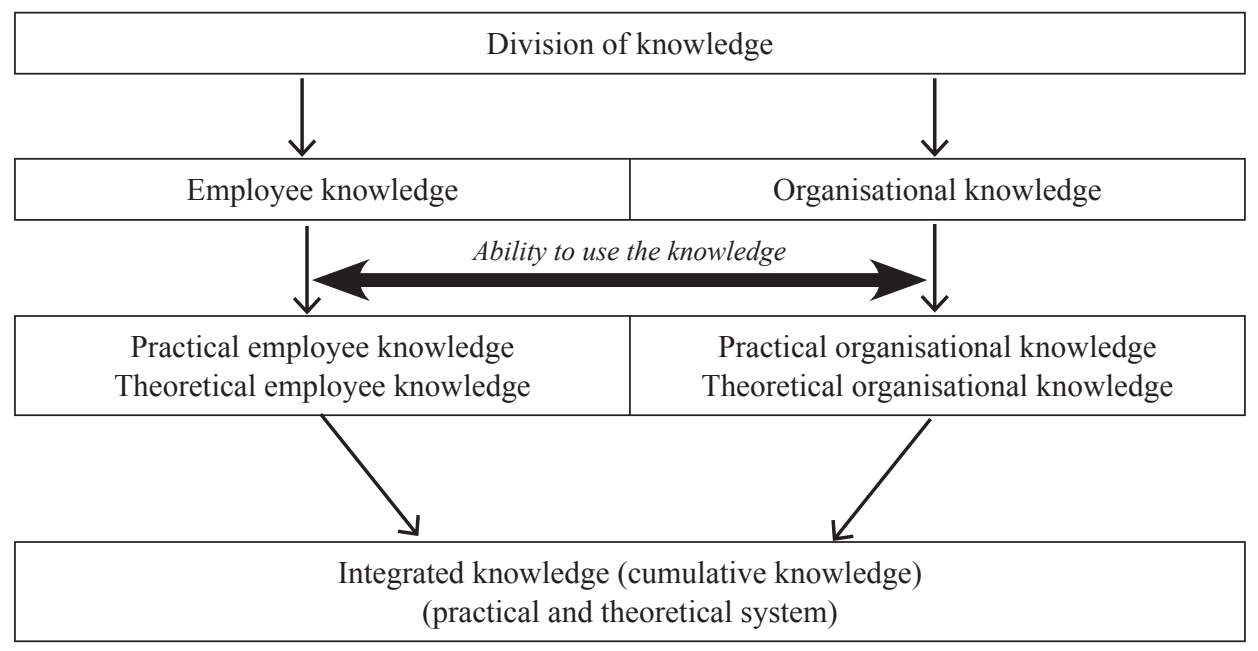

FIG. 3. Employee and organisational knowledge - the division of knowledge ${ }^{1}$.

Source: own elaboration based on Mikuła 2006, Mikuła and Pietruszka-Ortyl 2007, Leśniewski 2015.

\footnotetext{
${ }^{1}$ This division was first published in the following study. The author of this division is Michał A. Leśniewski.
} 
words a "practical and theoretical system". This system assumes that an organisation (enterprise) is of practical nature (practical knowledge) of functioning on the market whereas the development of an organisation is supported by the theory of learning (theoretical knowledge) transformed into practice (practical knowledge). It should also be taken into account that the practice of an organisation also supports the development of the theory of learning (theoretical knowledge). The use both of theoretical and practical knowledge requires the possession of appropriate skills, which should be treated as a transformer of theoretical knowledge into practical knowledge and vice-versa. It can be stated that the abilities are an adhesive which binds theoretical knowledge with practical knowledge, as well as employee knowledge with organisational knowledge. Mutual interpenetration of knowledge may be described as integrated knowledge.

Knowledge is the basis of existence of each organisation. Knowledge contributes to generating the resources of an enterprise. In the literature, the multitude of divisions of business resources origins, inter alia, from the development of the theory of learning (particularly economic sciences in the field of economics, economic sciences and humanities in the field of management), that is to say theoretical knowledge and practice - practical knowledge. Having the theoretical knowledge, practical knowledge or integrated knowledge give full grounds to generate new resources of an organisation. The result of generating is the generator as a new resource of an organisation. "Generating" is a process of creating new resources of an organisation, whereas the "generator" is understood as the result of generating, in other words the new resource of an organisation ${ }^{12}$. Qualitative employees and qualitative organisation form a strong basis for the use of knowledge in the process of generating resources of an organisation.

\section{SYNERGISM AND SYNERGY VERSUS THE RESOURCES OF AN ENTERPRISE}

In order for an enterprise to fulfil current and potential needs of the customers, it must be an active participant of the competitive market, it must have not only the resources, which are very important, but it also must be able to implement the process of synergism with a positive effect of synergy. "Synergism" may be defined as a process of cooperation, interaction of all the elements of an organisation in order to provide higher effectiveness and efficiency as a whole ${ }^{13}$. The result of synergism s synergy as "something" which is, which became a fact that it exists. Synergism and synergy must complement each other, because in such relations they will contribute to the growth of the value of an enterprise. In synergism and synergy, the knowledge plays a fundamental role, because the successes of an organisation is the knowledge that "something" can be done better than others do it

\footnotetext{
${ }^{12}$ The term and definition of "generating" and "generator" in the context of knowledge was created by Michał A. Leśniewski and first published in the following study.

Knowledge used in the process of "generating". Generator as the result of generating. An example of a generator may be a resource, a factor, etc., which did not exist earlier, but exists now.

${ }^{13}$ The definition of the term "synergism" was created by Michał A. Leśniewski This definition was first published in ths publication.
} 
and that "somebody" achieves better results than others. Without knowledge, it would be impossible to consider synergism and synergy.

Griffin states that good interpersonal relations in the whole organisation may also be the source of synergy. People who support each other and who cooperate well may achieve much more than people who do not support each other and who do not know how to cooperate [Griffin 2005].

It can be said that each aspect of functioning of an organisation may be a source of synergy. Each synergism which is to generate a positive effect of synergy must have its source in a positive potential of an organisation.

A manager, who must be comprehensively oriented in the sources which can create positive effect of synergy, is of great importance to the synergism. It may be stated that a manager is to be a mentor of the implementation of synergism in an organisation. A manager who is a mentor may be presented as a knowledge manager.

The literature provides a lot of examples of achieving a positive effect of synergy both in terms of qualitative research and quantitative research. One of the examples is the fact that [Romańczuk 2003]:

- sharing knowledge enabled to solve practical problems and to achieve business profits,

- staff are aware of the connection between the knowledge-sharing and business objectives, hence the initiative of the creation of teams of experts and discussion groups have had significant successes,

- knowledge-sharing is closely related to the core value of the company and enables its implementation,

- style of knowledge-sharing is matched to the style of work of the organisation,

- the managers promoted cooperation and knowledge,

- the practice of sharing knowledge is integrated into the daily rhythm of work,

- the level of involvement of managers is closely related to the overall level of commitment of the organisation to knowledge-sharing,

- in organisations, which are thought to be the best, a process of informal human networks takes place, which have huge impact on organisations. The scope of their expertise knowledge refers to the relevant areas of the company,

- formal or informal teams have a moderator who cares for everyone to actively participate in the work of the team,

- the best companies see the need to link the system of awards and accolades knowledge-sharing.

The above examples are the proof that synergism and synergy cannot function without knowledge. Knowledge may be defined as the source of synergism. In this case, a manager is justified as a manager coordinating various sources, which eventually are to generate a positive effect of synergy.

The resources of an enterprise are connected with knowledge, which marks the resources into the issue of synergism. Complementary and synergetic approach to the resources provides full grounds to talking about "complementary-synergetic resources". It can be stated that the resources which contribute to the development of an enterprise must be based on the complementarity and synergism. "Complementary-synergetic resources are the relations between the resources, which contribute to the mutual complementing of the resources and that the cooperation of several resources together give 
better benefits for an organisation than each separate resource" ${ }^{\prime 14}$. The resources seen in that way introduce an organisation into the "road" of dynamic look on an enterprise in changing surroundings.

\section{CONCEPTUAL MODEL OF KNOWLEDGE MANAGER}

Knowledge is inextricably linked with man (employee). Taking into account the relations in the organisations, including enterprises, we have to deal with managers and subordinates. One of the features, which characterize the employees is the fact that each of them has a different level of knowledge. While working together, the managers and the subordinates contribute to the synergism and the diversity of the resources of an economic operator. It is important to have such a level of knowledge which will enable the managerial staff to create the concept of mechanism contributing to the generating of synergism and the diversity of resources. Each enterprise is moving in the direction of being unique and unrepeatable on a competitive market. The knowledge constitutes the substance of both the manager and the subordinate.

Considering knowledge in the context of a manager [McKeen and Staples 2003] one can attempt to define the "concept of knowledge manager", which may be a "material concept", in other words, which concerns the physical, material position in an enterprise (included in the organisational structure - the position of knowledge manager having the scope of his responsibilities etc.), but it also may be an "immaterial concept" (there is no position in the organisational structure of an enterprise - there is no position of knowledge manager in an enterprise). Therefore, the concept of knowledge manager appear to be a dichotomous concept, that is to say, it has both material and immaterial form. Regardless of the adopted concept of the leading role of a knowledge manager is such use of his knowledge, which will lead the organisation to the achievement of the benefits from the market.

A knowledge manager [Asllani and Luthans 2003] would be responsible in an enterprise for, inter alia, the transfer of knowledge on the line, i.e.: business incubator (technology parks, academic business incubators, etc.) and an enterprise. A knowledge manager would contribute to drawing Business closer to Science or Science closer to Business [Mikuła and Oczkowska 2009]. They both have a lot to offer. The knowledge manager is not only a person working in an enterprise, but also a person working at universities or other scientific organisations. "A knowledge manager may be defined as a relevant person who knows how to use his knowledge in various ways. A knowledge manager is able to develop the concept of the transfer of knowledge between different organisations" $" 15$. In the era of knowledge-based economy it is reasonable to consider this concept

\footnotetext{
${ }^{14}$ The resources may also be seen in the category of "relations", in other words existing relations contribute to the creation of new, different resource.

The term and the definition of "complementary-synergetic resources" were developed by Michał A. Leśniewski and first published in this study.

15 The definition of "knowledge manager" was developed by Michał A. Leśniewski and was used first used in the following elaboration.
} 
of the manager from a long-term perspective of development of the organisation, both in companies and universities. In Figure 4 the conceptual model of knowledge manager was presented.

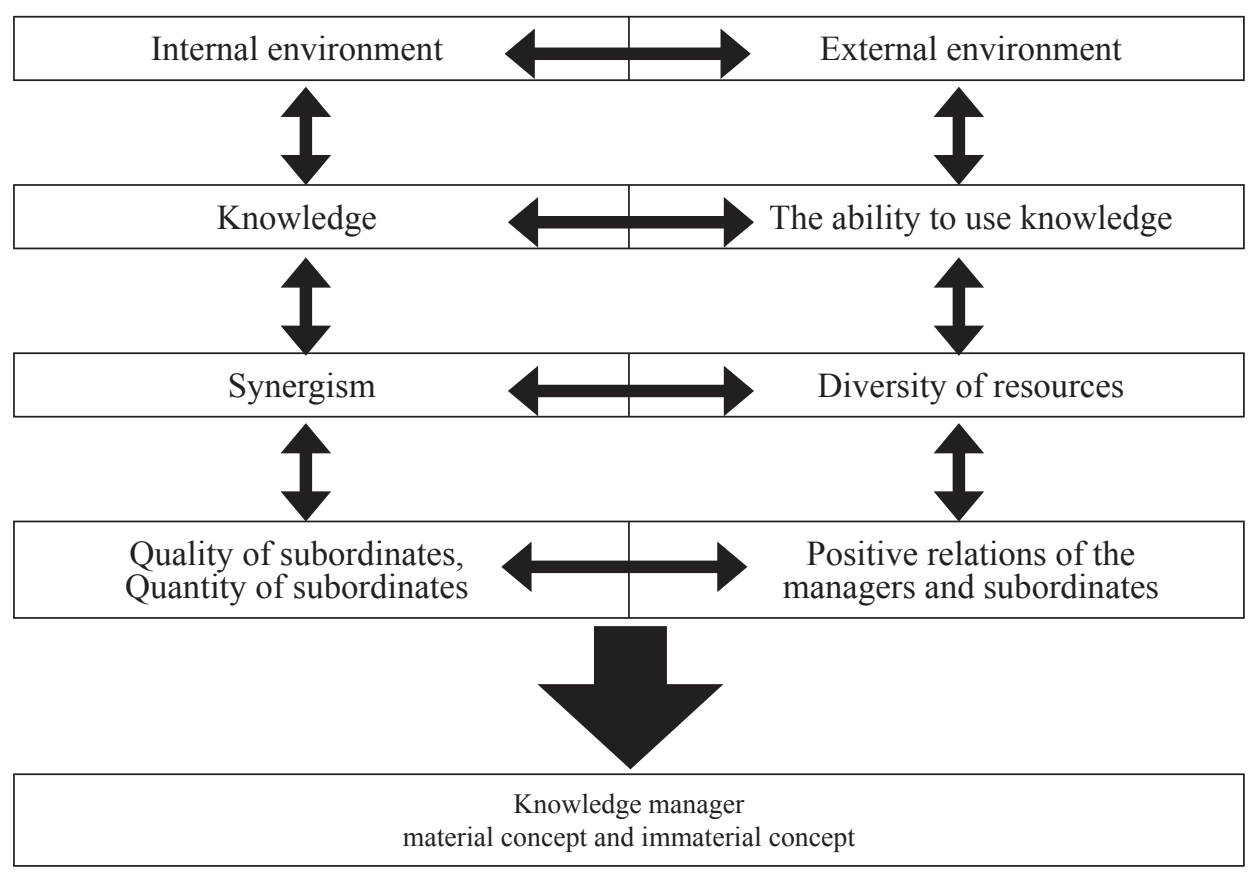

FIGURE 4. Conceptual model of knowledge manager

Source: own elaboration.

A knowledge manager is a managerial staff not only with a high level of relevance but also with a high level of responsibility for the transformations taking place in an economic operator. A model of knowledge manager which was presented in Figure 4 is an interpretation of an individual approach of the author to this model. This model is to be fully adapted to the conditions of functioning of any enterprise. The starting point of the analysis of the model of knowledge manager is the interpenetration of the internal and external environment. In order for the knowledge to cause benefits for an organisation, a component of the ability of using the knowledge must be added [Krogh 1998]. The knowledge and abilities are a typical example of complementarity and synergism. In an organisation, a manager must also implement the process of synergism and generate a diversity of the resources, which will increase the value of an organisation in its functioning on the market. In the diversity of the resources on can see - metaphorically speaking - so called "bottomless pit", where you can come across such resources which do not exist at present and after some time these resources appear (interpretative 
approach). Another element of the above model is the quality and quantity of subordinates. The subordinates as the employees of an organisation are presented in two categories: quantity and quality. The author of the model is the supporter of the qualitative approach to the subordinates, assuming that it is not the quantity but the quality which is the proof of the value of an employee - subordinate. Taking into account the fact that the other side of the employees in an organisation is the quantity, then one should generate skilfully the quality of employees from their quantity. A quality employee gives more of himself than a quantity employee. The quality and quantity of employees shapes the relations on the line: manager - subordinate. These relations mainly refer to the creation of positive approach towards a man. A manager is to understand a subordinate and a subordinate is to understand a manager. All of the factors presented above are a part of the concept of the model of a knowledge manager understood in the categories of material and immaterial concept. Both these concepts present the value of the model of a knowledge manager.

\section{CONCLUSIONS}

The resources play an important role in shaping the widely understood development [Bratnicki 2001], as well as they form the competitiveness of the enterprises. In order for the resources to "live" their life in an organisation, they must have defined attributes which include, inter alia, synergism, diversity and a knowledge manager. A unit which generates the knowledge, synergism or diversity is the manager as a person who is the source of implementation of the process of organisation management. In the process of management [Glinka 2008], the subordinates also appear, with whom the manager creates a network of relations of different nature. A knowledge manager should know how to use his knowledge to the achievement of the intended target. The material or immaterial form of the knowledge manager presents the value of all the activity subordinated to the operational and strategic aim of an enterprise. The problem of synergism and diversity of resources is a challenge for the knowledge manager, who will be able to implement the processes in an organisation with his intellect in such a way, that they will lead to generating new resource/resources. The knowledge in an organisation may take various forms just as different are the forms of a knowledge manager as a material and immaterial concept.

The person of a knowledge manager is a unit of main interest of the research issue brought up in this study. He is a stimulator of any changes occurring in the enterprise also taking into account external conditions of the economic operator. Conceptual model of a knowledge manager, which should be subjected to the process of empiric verification, is an authorial interpretation of the literature of the subject. This model, which subjected to becoming practical in the companies, will provide the rightness of the value of the knowledge, not only for the theory of science, but also the economic practice of various organisations. 


\section{REFERENCES}

ASLLANI A., LUTHANS F., 2003. What knowledge managers really do: an empirical and comparative analysis, Journal of Knowledge Management, 3, 53-66.

BRATNICKI M., 2001. Przedsiębiorczość i dynamika organizacji (Entrepreneurship and dynamics of the organisation) [in Polish], Organizacja i Kierowanie 2, 3-13.

CYFERT S., 2006. Strategiczne doskonalenie architektury procesów w zarządzaniu przedsiębiorstwem (Strategic improvement of architecture of processes in an enterprise management) [in Polish], Akademia Ekonomiczna w Poznaniu, Poznań.

DOBIJA D., 2003. Metodyka szacowania wiedzy (Knowledge estimation methodology) [in Polish] (in:) B. Wawrzyniak (ed.), Zarządzanie wiedzą w przedsiębiorstwie, Wyższa Szkoła Przedsiębiorczości i Zarządzania im. L. Koźmińskiego, Warszawa.

GLINKA B., 2008. Delegowanie uprawnień jako czynnik rozwoju małych przedsiębiorstw (Delegation of powers as a factor for development of small enterprises) [in Polish], Master of Business Administration 6, 100-106.

GRIFFIN R.W., 2005. Podstawy zarządzania organizacjami (Basics of organisation management) [in Polish], PWN, Warszawa.

JAKI A., 2012. Mechanizmy procesu zarządzania wartością przedsiębiorstwa (Mechanisms of enterprise value management process) [in Polish], Uniwersytet Ekonomiczny w Krakowie, Kraków.

JUCHNOWICZ M., 2009. Kultura zaufania wyzwaniem współczesnego zarządzania kapitałem ludzkim (The culture of trust as the challenge of contemporary human capital management) [in Polish] (in:) M. Juchnowicz (ed.), Kulturowe uwarunkowania zarządzania kapitałem ludzkim, Oficyna a Wolters Kluwer business, Kraków, 173-182.

KROGH G., 1998. Care in Knowledge creation, California Management Review 40, 133-153.

KOZINA A., 2014. Koncepcja dwuwymiarowej oceny kompetencji negocjacyjnych (The concept of two-dimensional evaluation of negotiation competences) [in Polish], Organizacja i Kierowanie 3, 69-81.

LEŚNIEWSKI M.A., 2013. Ekorozwojowe źródła konkurencyjności gmin w Polsce (Ecodevelopmental sources of competitiveness of municipalities in Poland) [in Polish], CeDeWu, Warszawa.

LEŚNIEWSKI M.A., 2014. Konkurencyjność zasobowa przedsiębiorstw (The Resource Competitiveness of Enterprises) [in Polish], Ekonomika i Organizacja Przedsiębiorstwa 4, 59-62.

LEŚNIEWSKI M.A., 2015. Wiedza w strategiach zarządzania przedsiębiorstwem. Zarządzanie wiedzą. Studium teoretyczne (Knowledge in business management strategies. Management of knowledge. Theoretical study) [in Polish] (in:) J. Jaskiernia, R. Kubicki (eds.), Ekonomia, zarządzanie i rozwój regionalny. Pomiędzy światem polityki a życiem naukowym. Księga jubileuszowa dedykowana Profesorowi Wojciechowi Saletrze, tom trzeci, Uniwersytet Jana Kochanowskiego, Kielce, 171-187.

McKEEN J.D., Staples D.S., 2003. Knowledge managers: Who they are and what they do (in:) C.W. Holsapple (ed.), Handbook on knowledge management band, vol. 1, Berlin: Springer Verlag, 21-41.

MIKUŁA B., 2006. Organizacje oparte na wiedzy (Knowledge-based organisations) [in Polish], Akademia Ekonomiczna w Krakowie, Kraków. 
MIKUŁA B., PIETRUSZKA-ORTYL A., 2007. Kompetencje pracowników w perspektywie strategicznego zarządzania wiedzą w przedsiębiorstwie (Employee Competencies and Strategic Knowledge Management in the Enterprise) [in Polish], Zeszyty Naukowe Akademii Ekonomicznej 747, 49-73.

MIKUŁA B., OCZKOWSKA R., 2009. Transfer wiedzy między partnerami aliansu strategicznego (Knowledge transfer between strategic alliance partners) [in Polish], Organizacja i Zarządzanie 2, 121-137.

NONAKA I., TAKEUCHI H., 2000. Kreowanie wiedzy w organizacji. Jak spółki japońskie dynamizują procesy innowacyjne (Creating knowledge in the organisation. How Japanese companies dynamize innovation processes) [in Polish], Poltext, Warszawa.

OCZKOWSKA R., 2014. Rozwój zasobów ludzkich - istota, instrumenty, podmioty (Human resources development - essence, instruments, entities) [in Polish] (in:) R. Oczkowska, U. Bukowska (eds.), Rozwój zasobów ludzkich organizacji, Difin, Warszawa, 11-30.

PACHOLARZ W.M., 2016. Pojęcia wiedzy w teorii ekonomii (The concept of knowledge in economic theory) [in Polish], Ekonomika i Organizacja Przedsiębiorstwa 8, 3-19.

PERECHUDA K., 2005. Pracownicy wiedzy jako kreatorzy sieciowych potencjałów (Knowledge employees as creators of network potentials) [in Polish], Zarządzanie Zasobami Ludzkimi 5, 9-15.

POCZTOWSKI A., 2003. Zarządzanie zasobami ludzkimi. Strategie - procesy - metody (Human Resources management. Strategies - processes - methods) [in Polish], PWE, Warszawa.

PRZYBYTNIOWSKI J.W., 2013. Konkurencyjność rynku usług pośrednictwa ubezpieczeniowego w Polsce (Competitiveness of the insurance brokerage services market in Poland) [in Polish], Wydawnictwo Menedżerskie PTM, Warszawa.

ROMANOWSKA M., 2001. Kształtowanie wartości firmy w oparciu o kapitał intelektualny (Shaping company value based on intellectual capital) [in Polish] (in:) R. Borowiecki (ed.), System informacji strategicznej. Wywiad gospodarczy a konkurencyjność przedsiębiorstwa, Difin, Warszawa, 30.

ROMAŃCZUK A., 2003. Praktyka zarządzania wiedzą w przedsiębiorstwie (Knowledge management practice in an enterprise) [in Polish] (in:) B. Wawrzyniak (ed.), Zarządzanie wiedzą w przedsiębiorstwie, Wyższa Szkoła Przedsiębiorczości i Zarządzania im. L. Koźmińskiego, Warszawa, 141.

RZEPKA A., 2015. The knowledge-based economy, international trade and FDI as the main trends in contemporary processes of globalisation: the case of Poland, International Journal of Arts and Sciences 3,121 - 132.

SUŁKOWSKI Ł., 2012. Kulturowe procesy zarządzania (Cutlural management processes) [in Polish], Difin, Warszawa.

SKOWRONEK-MIELCZAREK A., 2012. Zasoby w rozwoju przedsiębiorstwa (Resources in Corporate Growth) [in Polish], Studia i Prace Kolegium Zarządzania i Finansów 121, $127-143$.

WOJTCZUK-TUREK A., 2008. Kompetencje twórcze jako istotny składnik kapitału innowacyjnego przedsiębiorstw (Creative competences as a significant component of the innovative capital of enterprises) [in Polish] (in:) S.A. Witkowski, T. Listwan, (eds.), Kompetencje a sukces zarządzania organizacją, Difin, Warszawa, 471-483. 
Summary. One of the fundamental problems relating to the management of the company is the manager and its employees' as the human resource of the organisation. Managers with their staff and particularly positive relationship between them are able to build constructive foundation of the future undertakings. The aim of the white paper is to provide a fault energy and diversity of companies with the presentation of his concept of manager's model knowledge. In the development of the adopted research hypotheses formulated as follows: First hypothesis research area: knowledge manager is a wizard synergetic and diversity of companies, second hypothesis research area: meteoric manager is provided through knowledge and be able to use this knowledge, Third research hypothesis: manager knowledge can be reflected in the form of a concept of material and the concept of an intangible asset. The development of a conceptual design and is based on the method of interpretation literature.

Key words: manager knowledge, diversity enterprise resource, business management

JEL: O15, D83

Corresponding authors: Michał Adam Leśniewski, The Jan Kochanowski University in Kielce, The Faculty of Management and Administration, Poland, e-mail: michaladam.lesniewski@wp.pl; Wioletta Magdalena Pacholarz, AGH University of Science and Technology, Faculty of Management, Poland, e-mail: wiolettapcholarz@vp.pl

Received: $\quad 16.06 .2017$

Accepted: 15.04 .2018 